\title{
When a mature technology company pivots: A case study of Logitech
}

\author{
Anderson Darrell a*, Daniel K.N. Johnson ${ }^{b}$ \\ a Product Manager, FSharp, 140 E 30th Street, New York City, NY. \\ b Schlessman Professor of Economics, Colorado College, CO, 80903. E-mail: djohnson@ColoradoCollege.edu. \\ *Corresponding author's email address: abdarrell@gmail.com.
}

\section{A R T I C L E I N F O}

Received: 08-08-2016

Accepted: 28-08-2016

Available online: 30-08-2016

Keywords:

Life cycle theory;

Logitech; pivot; stock price.

\begin{abstract}
A B S T R A C T
Life cycle theory has been shown to be an important explanation of the relationship between sales and stock prices. This study explores how the technology company Logitech attempted a transition from a mature life-cycle company in computer peripherals to a growth company in the music, tablet, and gaming industries. We show that stock price correlates with accounting performance differently across the company's life cycle.
\end{abstract}

JEL Classification :

G12; G14; L63; 032; 033.

(C) 2016 The Authors. This is an open access article under the terms of the Creative Commons Attribution License 4.0, which allows use, distribution and reproduction in any medium, provided the original work is properly cited.

\subsection{Motivation}

There is a deep literature documenting life-cycle paths for firms, and an equally deep literature correlating stock prices with accounting fundamentals (Anthony and Ramesh, 1992). However, to our knowledge, there are no studies of how this underlying pattern of accounting fundamentals might reflect a mature technology company attempting to pivot to trending markets far outside the scope of its pre-established business. In a nimble economy, it seems unremarkable that such cases will occur; indeed, we analyze here the case of Logitech, an established technology company with a significant global presence that decided to redirect its future from computer peripherals into quite unrelated (yet still technological) markets: the music, tablet and gaming sectors.

Logitech started in 1976 as a computer peripheral company, incorporating in 1981 and marketing their first computer mouse in 1982 (Logitech, 2007). They expanded internationally (to Ireland and then to China) to produce more efficiently, expanding to scanners and digital cameras by 1992 . Web cameras and cordless devices followed in the early 2000s. The company made a much-publicized pivot in 2012 under a new Chief Executive Officer to focus on gaming and music. The authors chose this company as a sample of convenience; personal contacts within the company made it possible to obtain financial data for a case study of this nature.

To communicate clearly with the existing literature, we analyze the recent history of Logitech using the standard model of the business life cycle, empirically testing how the relationships between accounting fundamentals and stock price respond during the pivot period, and reflect on how redirection might affect standard life cycle theory. The remainder of the paper is organized in standard fashion: section 2 is a literature review, section 3 outlines the model, section 4 describes our data, section 5 reports our results, and section 6 reflects on the implications of the analysis for theory and empirical study in the future. 


\section{$2.0 \quad$ Literature review}

Building on the seminal work of Modigliani (1966) who asserted that households followed a life cycle of savings, Ball and Brown (1968) argued that investor sentiment must expect the same behavior of firms. They found that the accounting fundamentals of firms also regularly showed departures from market efficiency, displaying rampant examples of seemingly irrational behavior around announcement dates where annual reports resulted in abnormally large changes in stock prices. By sampling announcement data, Beaver (1968) created an earnings response model that classified a company's stock price according to risk and volatility, confirming and extending Ball and Brown's (1968) results; not only prices, but price volatility and market volume responded disproportionately upon the arrival of news. Benston (1972) argued that previous studies missed the important 'utility' of news to investors, since risk-aversion obviously played a role in investor responses.

Boston Consulting Group (1972) introduced the idea of an "experience curve", that the accounting costs of a firm decline with the experience of a firm, other things held equal. In short, depending on the maturity of a firm, the same accounting values might mean very different results for profits (and therefore, for investors). Atiase (1985) and Freeman (1987) added to this insight by empirically showing that a firm's size and input magnitudes change the relationship between accounting fundamentals and stock price. Freeman (1987) showed that stock prices for large firms are anticipated earlier than those of small firms and that smaller firms tend to exhibit higher levels of "unexpected" results. Reversing the tests, Beaver (1968), Collins et al. (1987) and Collins and Kothari (1989) asked whether stock prices could in turn re-predict accounting values but found disconcertingly weak results, suggesting a unidirectional causality (if indeed, even that one direction worked consistently).

Upon this historical literature, Anthony and Ramesh (1992) proposed a working model of how life cycle theory applies to the relationship between a company's stock price and its accounting performance measures. Using data on over 3,000 firms, they assigned life stages to each firm based on three key variables: dividends paid, sales growth, capital expenditures. Unexpected stock price changes were modeled as a linear function of these variables, with the function varying by the period of the firm's life cycle.

Recent work on Life Cycle Theory has slowed for firm-base analysis, focusing instead on whether the same models might hold true for individuals. Deaton (2005) and Mankiw (2009) tested whether predictions about consumption and saving behavior depend on the Life Stage label of a person.

\subsection{Model}

We build our work on the baseline model of Anthony and Ramesh (1992), where abnormal stock returns (AR) for any firm are influenced by changes in earnings (IBED, or income before extraordinary or discontinued items), changes in capital expenditures (CE), changes in sales growth (SG) and the firm's life cycle stage (as indicated by a dummy variable) here:

$$
A R=D_{i}(\triangle I B E D+\triangle C E+\triangle S G)+u
$$

However, this simple model assumes away much of the interesting complexity in considering a mature company that pivots into a different economic sector. For example, sales might remain constant but represent enormous growth in a new sector simultaneous with withdrawal from an old sector. Thus, in the case of Logitech we distinguish between "old sector sales" (in their case, personal computer peripheral equipment, SG1) and "new sector sales" (in their case, music, gaming and tablet equipment, SG2):

$$
A R=D_{i}(\triangle I B E D+\triangle C E+\triangle S G 1+\Delta S G 2)+u
$$

To test the fit of this model, we follow the accounting data for Logitech before and after their pivot year (2012). That year was chosen as the pivot year after personal conversation with administrators in the company, after comparison of trends in each key variable for points of inflection, and in accordance with significant news at the firm: the election of a new Chief Executive Officer with a mandate to change course. In contrast, we identified the 2000-2004 period as a period of stagnancy for Logitech, where its core business never showed strong growth. After that period, accounting values seemed to be more in line with a growth or mature life cycle stage. Our results tested for robustness around the precise date of movement from growth to mature life cycle stage.

\subsection{Data}

We were privileged to obtain accounting data from Logitech for the 54 financial quarters of our study through personal contacts within the company. However, due to the proprietary nature of the data, we may only describe their definitions here. 
The independent variables of our analysis (IBED, CE, SG1, and SG2) are taken as changes between their annual averages before their pivot (2012) and after their pivot (post-2012). All are measured in millions of real dollars, so the dependent variable AR is also in those units. Stock price is public information from the NASDAQ exchange.

\subsection{Results}

Primary results as presented in Table 1 use standard definitions of the life cycle stages, matching the approach of Anthony and Ramesh (1992). Each fiscal quarter of each year is therefore categorized according to their definitional breakpoints. However, alternative breaks for each life cycle offer extremely similar results, both qualitatively and quantitatively. Standard tests on the errors (tests for heteroskedasticity, first-order autocorrelation, multicollinearity and normality) show predictable but modest problems; Prais-Winston corrections change little in the flavor of the results, and we report robust standard errors here with an acknowledgement of potential biases due to high correlations between explanatory variables. We elect to report the results as they accord with theory, recognizing that unavoidable multicollinearity predisposes our coefficients toward statistical insignificance.

\begin{tabular}{llll}
\hline \multicolumn{4}{c}{ Table 1: Estimation results } \\
\hline Life Cycle Stage & Variable & Coefficient & t-statistic \\
\hline Stagnant & Earnings (IBED) & -0.013 & $(0.89)$ \\
& Capital expend. (CE) & 6.719 & $(1.04)$ \\
& Sales growth (SG1, old) & 0.129 & $(1.34)$ \\
& Sales growth (SG2, new) & -0.005 & $(0.13)$ \\
Growth & Earnings (IBED) & $3.720 \times 10^{-7}$ & $(0.47)$ \\
& Capital expend. (CE) & -4.268 & $(0.54)$ \\
& Sales growth (SG1, old) & -0.072 & $(1.89)^{*}$ \\
Mature & Sales growth (SG2, new) & 0.100 & $(4.68)^{* * *}$ \\
& Earnings (IBED) & -0.002 & $(0.22)$ \\
& Capital expend. (CE) & -12.135 & $(1.49)$ \\
Constant & Sales growth (SG1, old) & 0.010 & $(0.27)$ \\
Observations & Sales growth (SG2, new) & -0.006 & $(0.24)$ \\
Adjusted R ${ }^{2}$ & & 16.057 & $(15.14)^{* * *}$ \\
& & & 54 \\
& & & 0.398
\end{tabular}

Notice that the prominent pattern is a simple one: the linear constant is by far the most important factor in determining stock price.

Interestingly though, the only other statistically significant variable is sales growth, which pivots demonstrably not only in size but actually in sign, as the company moves from an old business line to a new business line. In other words, increased sales in their old market niche are actually interpreted by investors as a negative, a detriment to stock price appreciation, while sales growth in the new market niche is understandably seen as a factor that favors stock price rises.

Perhaps even more significantly, this pivot is only seen when the company is in its growth phase; while the firm is either stagnant or mature, the impact of sales growth in either market niche (old or new) is statistically irrelevant to stock prices. Naturally, this could be due to multicollinearity concerns over the subsamples in those life cycle periods. However, it might suggest that investors watch sales composition more carefully during growth periods than they do during more stable periods.

\subsection{Conclusion}

The goal of this paper was to explore the applicability of Anthony and Ramesh (1992) model relating accounting performance measures to stock price over the life cycle of a firm, to explore its usefulness specifically for a seasoned technology-based firm engaged in a market pivot from computer peripherals to a focus in other electronics. We appear to have found that while the model has limited explanatory power, investors may be keying on precisely the issue that concerns us the most: sales growth in the old market niche versus sales growth in the new market niche. In fact, investors may actually be seeing sales growth as a detrimental factor if it occurs in the old market. If replicable with other firms in similar circumstances, there are implications of this result for investors, for business leaders and for policymakers alike. 
The implications are important not only for investors but for business leaders and for policymakers. Investors should be particularly careful in reading sales reports for growth-stage firms engaged in a pivot, as a decomposition of sales by sector appears to be warranted. There appears to be value in a careful reading of how quickly and thoroughly the pivoting growth-stage company is earning sales in the new sector instead of the old sector; even if that does not matter to the firm's accounting fundamentals, it matters to other investors who are contributing to the stock's price.

As a business leader, the timing of the announcement of a potential pivot and the speed of execution of that pivot appear to be important. Investors appear to favor the quick pivot rather than the slow transition, at least for a growth-stage company, so a strategic timing of the pivot announcement seems wise.

Finally, policymakers should be aware that growth-stage firms are sensitive to this investor phenomenon. In regions or time periods where many growth-stage firms are pivoting, we may see stock market declines regardless of the underlying accounting fundamentals. Assistance that can be offered to speed the transition, to reduce structural tensions as firms adjust and adapt, alongside patience with the ambiguity during the pivot, would seem to be warranted.

Clearly, there are limitations to the current study, most notably that we investigate only one company for which data were available to us. For example, we cannot comment on whether the effects we see are unique to this firm, unique to this economic sector, or unique to this particular pivot at this point in time. We look forward to exploring and comparing the phenomenon of the pivot among other established technology firms as examples and data become available.

\section{Bibliography}

Anthony, J.H. and K. Ramesh (1992). "Association between Accounting Performance Measures and Stock Prices." Journal of Accounting and Economics 15(2-3):203-27. http://dx.doi.org/10.1016/0165-4101(92)90018-W

Atiase, K. (1985). "Predisclosure Information, Firm Capitalization, and Security Price Behavior around Earnings Announcements". Journal of Accounting Research 23(1): 21-36. http://dx.doi.org/10.2307/2490905

Ball, R. and P. Brown (1968). "An Empirical Evaluation of Accounting Income Numbers." Journal of Accounting Research 6(2): 159-160. http://dx.doi.org/10.2307/2490232

Beaver, W.H. (1968). "The Information Content of Annual Earnings Announcements." Journal of Accounting Research 6: 67-68. http://dx.doi.org/10.2307/2490070

Benston, G.J. (1972). "Economies of Scale of Financial Institutions." Journal of Money, Credit and Banking 4(2): 312-314. http://dx.doi.org/10.2307/1991041

Boston Consulting Group (1972). Perspectives on Experience. Boston.

Collins, D.W. and S.P. Kothari (1989). "An Analysis of Intertemporal and Cross-sectional Determinants of Earnings Response Coefficients." Journal of Accounting and Economics 11(2-3): 143-81. http://dx.doi.org/10.1016/0165-4101(89)90004-9

Collins, D.W., S.P. Kothari and J.D. Rayburn (1987). "Firm Size and the Information Content of Prices with Respect to Earnings." Journal of Accounting and Economics 9(2): 111-38. http://dx.doi.org/10.1016/01654101(87)90002-4

Deaton, A. S. (2005). Franco Modigliani and the Life Cycle Theory of Consumption. SSRN Electronic Journal SSRN Journal. doi:10.2139/ssrn.686475

Freeman, R.N. (1987). "The Association between Accounting Earnings and Security Returns for Large and Small Firms." Journal of Accounting and Economics 9(2): 195-228. http://dx.doi.org/10.1016/01654101(87)90005-X

Hagerman, R.L. (1984). "The Association between the Magnitude of Quarterly Earnings Forecast Errors and RiskAdjusted Stock Returns." Journal of Accounting Research 22(2): 526-40. http://dx.doi.org/10.2307/2490662

Logitech (2007). Logitech History. Downloaded from http://www.logitech.com/lang/pdf/logitech_history_2007 03.pdf on October 4, 2016.

Mankiw, N. Gregory (2009). Macroeconomics (Seventh ed.). New York: Worth. pp. 509-513. ISBN 978-1-42921887-0

Modigliani, F. (1966). The Life Cycle Hypothesis of Saving, the Demand for Wealth and the Supply of Capital, 1966. 